\title{
Pengembangan Alat Ukur Sikap Nasionalisme pada Mahasiswa
}

\author{
Hafnidar Hafnidar ${ }^{1}$, Maya Karina ${ }^{1}$, Cut Meurah Hadiah ${ }^{1}$ \\ ${ }_{1}^{1}$ Program Studi Psikologi, Fakultas Kedokteran, Universitas Malikussaleh, Aceh Utara
}

DOI: http://doi.org/10.29080/jpp.v12i1.528

\begin{abstract}
The globalization era not only gives a change towards individual success but also reduce nationalism attitude. This research aims to develop nationalism attitudes scale. There are seven aspects of nationalism which are constructed in this scale which are tolerance, responsibility, willing to sacrifice, courtesy, caring for others, willing to use domestic products, and loving own culture. There are 100 students of Malikussaleh University, North Aceh involved in the testing of this scale. The results showed that the reliability value was 0.808 and classified high. In other words, this nationalism attitude scale can be trusted. The exploratory analysis was resulted in five components of the nationalism attitude which consist of 38 items.
\end{abstract}

Keywords : nationalism, nationalism attitude, college student

\begin{abstract}
Abstrak : Era globalisasi tidak hanya dapat memberi perubahan ke arah keberhasilan individu tetapi juga menyebabkan berkurangnya sikap nasionalisme, yaitu pengikisan identitas nasional bangsa. Budaya-budaya luar yang begitu mudah diserap oleh setiap masyarakat Indonesia, seperti gaya bahasa, fashion, perilaku, gaya berbicara, hingga pola pikir juga memberikan sumbangan terhadap nasionalisme tersebut. Penelitian ini bertujuan untuk mengembangkan alat ukur sikap nasionalisme. Ada tujuh aspek yang digunakan dalam menyusun skala sikap nasionalisme ini yaitu toleransi, tanggung jawab, rela berkorban, sopan santun, peduli terhadap sesama, bersedia menggunakan produk dalam negeri, dan mencintai budaya sendiri. Sebanyak 100 mahasiswa Universitas Malikussaleh, Aceh Utara dilibatkan dalam uji coba alat ukur ini. Hasil penelitian menunjukkan nilai reliabilitas yang tergolong tinggi yaitu 0.808 . Dengan kata lain alat ukur sikap nasionalisme ini dapat dipercaya. Hasil analisis eksploratori yang dilakukan peneliti menghasilkan lima komponen penyusun sikap nasionalisme yang terdiri dari 38 item.
\end{abstract}

Kata kunci : nasionalisme, sikap, mahasiswa

Corresponding Author: Hafnidar (e-mail: hafnidar@unimal.ac.id) Program Studi Psikologi, Fakultas Kedokteran, Universitas Malikussaleh, Cot Tengku NieReuleut, Muara Batu, Aceh Utara, Aceh, Indonesia 


\section{Pendahuluan}

Sikap nasionalisme merupakan salah satu hal yang wajib dimiliki oleh setiap individu dan masyarakat yang hidup di Indonesia. Seiring perkembangan zaman, semakin banyak tantangan dan persoalan yang dihadapi bangsa Indonesia baik secara internal maupun eksternal. Selain itu kehadiran globalisasi membawa pengaruh dalam kehidupan suatu bangsa di berbagai aspek, seperti sosial, politik, ekonomi, budaya dan banyak hal lainnya (Triantoro, 2008). Namun, tidak dapat dipungkiri bahwa hal ini juga dapat menyebabkan pengikisan identitas nasional bangsa. Budaya-budaya luar yang begitu mudah diserap oleh setiap masyarakat Indonesia, seperti gaya bahasa, fashion, perilaku, gaya berbicara, hingga pola pikir ikuit memberikan sejumlah perubahan (Mardapi, 2005).

Masuknya budaya asing ke dalam Indonesia membawa pengaruh besar yang mengakibatkan berkurangnya semangat kebangsaan. Hal ini ditandai dengan terkikisnya akhlak, moral, rasa bangga, rasa cinta tanah air dan sikap bangsa Indonesia khususnya generasi penerus. Fenomena ini dapat dilihat dari generasi muda ketika berkomunikasi dengan individu yang lebih tua kurang mengedepankan nilai-nilai sopan-santun (Mutia, 2018). Selain juga dapat dilihat dari semakin banyak kecenderungan generasi muda khususnya milenial dalam bersikap individualis yang juga disebabkan karena semakin ketatnya persaingan antar individu dikehidupan nyata (Aviani, 2019). Pengaruh lain dari globalisasi adalah berkembang pesatnya barang-barang produksi luar negeri sehingga generasi muda menganggap pakaian luar negeri lebih baik dibandingkan pakaian khas Indonesia, sehingga enggan menggunakan pakaian yang menjadi ciri khas dan jati negara Indonesia (Suriata, 2019).

Adanya keyakinan baru bahwa masyarakat sekarang bukan hanya masyarakat lokal, tetapi sudah menjadi masyarakat global juga berdampak pada kaburnya nilai-nilai dan sikap nasionalisme yang telah dibentuk sebelumnya (Manan, 2011). Selain itu, Anwar (2014) semangat kedaerahan yang terlalu tinggi dapat melunturkan nasionalisme seseorang, sehingga dapat mengarah kepada etno-nasionalisme dan separatisme.

Bausan (2012) menyatakan bahwa perbedaan nasionalisme pada masa sebelum kemerdekaan dan nasionalisme pada masa sekarang disebabkan oleh beberapa faktor, diantaranya perubahan tatanan sosial, politik, dan ekonomi. Hal ini disebabkan karena pengaruh globalisasi yang pelan-pelan melunturkan nasionalisme yang sudah melekat pada masyarakat Indonesia. Fenomena itu menjadi tantangan terbesar masyarakat Indonesia dalam menanamkan sikap nasionalisme khususnya bagi generasi penerus bangsa. Jika sikap nasionalisme mulai terkikis atau bahkan tidak terbentuk, maka akan menyebabkan perpecahan yang sangat memberikan dampat negatif akan persatuan dan kesatuan bangsa sehingga menjadi penting dalam mengembangkan alat ukur sikap nasionalisme.

Affan dan Hafidh (2016) mengartikan nasionalisme sebagai kesatuan antar individu yang mempunyai kesamaan budaya, bahasa, dan sejarah pemerintahan. Nasionalisme merupakan sifat positif yang muncul dari masyarakat sejak masa kemerdekaan hingga masa sekarang yang berbentuk sikap patriotik yang akhirnya diterapkan individu dalam kesehariannya (Sardjo dan Setiawan, 2019). Toto Parmoto (2012) berpendapat bahwa nasionalisme merupakan kesadaran setiap masyarakat dalam suatu negara yang berkewajiban untuk mencintai dan membela negaranya sendiri sehingga menjadi landasan dalam membentuk semangat kebangsaan Indonesia. Selanjutnya, nasionalisme didefinisikan sebagai perasaan mendalam yang erat kaitannya dengan tanah air, tradisi, dan pemerintahan resmi daerahnya, sehingga disimpulkan kesetiaan tertinggi harus ditujukan kepada bangsa dan Negara sendiri (Gandhi, 2012).

Sementara itu, sikap nasionalisme didefinisikan sebagai respon yang muncul dari diri individu terhadap rasa berani berkorban demi kepentingan bangsa atau kepentingan bersama yang dapat berbentuk semangat patriotik sebagai bukti nyata akan kesetiaan 
serta kecintaan terhadap tanah air (Mustari, 2014). Sadikin (2008) mendefinisikan sikap nasionalisme sebagai sikap akan rasa cinta bangsa, tanah air, dan Negara yang menyatu dalam sikap ekonomi, budaya, politik, dan sosial sebagai wujud persatuan dan kemerdekaan nasional. Oleh karena itu, sikap nasionalisme harus ditanamkan dan dibentuk dalam diri setiap penerus bangsa. Penerus bangsa yang dimaksud seperti pelajar (siswa atau mahasiswa) yang dapat dikenalkan melalui lingkungan keluarga, masyarakat, atau sekolah. Hal ini sejalan dengan pendapat Tilaar (2007) bahwa sikap nasionalisme harus dikembangkan dalam proses di bidang pendidikan sehingga dapat dijadikan sebagai modal kultural. Dengan demikian dapat disimpulkan bahwa sikap nasionalime adalah keinginan yang ada dalam diri individu untuk menunjukkan, kesetiaan, kecintaan, dan kebanggaan akan tanah air sehingga selalu berusaha mempertahankan kedaulatan dan memajukan bangsa serta negaranya.

Adapun prinsip sikap nasionalisme menurut Sartono Kartodirejo (dalam Moesa, 2007) ada lima yaitu kesatuan, kemerdekaan, kesamaan, dan kepribadian. Kesatuan merupakan syarat paling penting dan tidak dapat ditolak dalam menjaga keutuhan bangsa dan negara ini. Adapun kemerdekaan merupakan kebebasan dalam bertindak dan juga memberikan pendapat yang tentunya tetap mengikuti koridor yang ditetapkan di negara ini. Selanjutnya prinsip kesamaan berlaku untuk seluruh masyarakat dalam mengembangkan keterampilan dan kemampuannya. Prinsip terakhir adalah kepribadian yang terbentuk berdasarkan sejarah bangsa dan pengalaman budaya.

Nilai-nilai nasionalisme menurut Gunawan Restu (1998) terdiri dari mendahulukan kepentingan bersama dibandingkan kepentingan diri sendiri, memiliki semangat berkorban dan senantiasa mengabdikan diri kepada bangsa serta negara, pantang menyerah dalam membela kepentingan bangsa, dan memiliki sikap menjaga persatuan dan kesatuan bangsa. Selain itu nasionalisme juga menunjukkan sikap patriotik dalam mempertahankan kemerdekaan dan memajukan negara, bangga, menjaga, serta melestarikan budaya milik bangsa, mampu bekerjasama dalam membangun dan memajukan bangsa dan mampu mengontrol diri sendiri demi kepentingan persatuan dan kesatuan bangsa. Nilai nasionalisme selanjutnya adalah memiliki keinginan kuat dalam memperbaiki diri dan tenggang rasa, bersikap adil, memiliki semangat kemerdekaan dan cinta perdamaian, bertahan dalam situasi apapun, ulet, dan tahan uji dalam membela dan membangun bangsa dan jujur terhadap sesama dan diri sendiri. Kedua teori di atas saling melengkapi sehingga penyusunan alat ukur dalam penelitian disimpulkan menjadi toleransi, tanggung jawab, rela berkorban, sopan santun, peduli terhadap sesama, bersedia menggunakan produk dalam negeri, dan mencintai budaya sendiri.

Penelitian terdahulu mengenai pengembangan alat ukur sikap Nasionalisme yang dibuat oleh Sardjo dan Setiawan (2019) menggunakan 4 aspek, yaitu patriotik, rela berkorban, melestarikan budaya, dan peduli terhadap sesama. Alat ukur tersebut diujicobakan pada siswa sekolah menengah pertama dengan hasil akhir 25 item valid yang dapat digunakan. Selain itu, Yasa (2012) melakukan pengembangan alat ukur Sikap Nasionalisme pada siswa Sekolah Menengah Atas dengan indeks validitas 0.94 dan 35 item valid yang dibentuk berdasarkan 3 dimensi aspek, yaitu toleransi, kerja sama, dan tanggung jawab. Sementara pengembangan alat ukur Sikap Nasionalisme dalam penelitian ini menggabungkan teori sikap nasionalisme yang dikemukakan oleh Sartono Kartodiredjo (1967, dalam Moesa, 2007) dan Gunawan Restu (1998) yang diujicobakan pada mahasiswa yang berada pada usia dewasa awal. Menurut Hurlock (1986) pada masa dewasa awal terjadi peralihan dari pandangan egosentris menjadi sikap yang empati, juga merupakan masa penyesuaian terhadap pola-pola kehidupan yang baru dan harapanharapan sosial yang baru.

Dalam penyusunan alat ukur, masalah yang pertama muncul dalam praktek pengukuran adalah seberapa baik instrumen atau alat ukur yang dibuat, uji validitas dan uji reliabilitas sangat penting sehingga menghasilkan alat ukur yang akurat dan dapat 
dipercaya (Azwar, 2002). Oleh karena itu alat ukur Sikap Nasionalisme dalam penelitian ini didasarkan atas analisis eksploratori untuk mengetahui faktor-faktor apa saja yang terbukti kuat menggambarkan sikap nasionalisme seorang mahasiswa yang berada pada usia dewasa awal.

\section{Metode Penelitian}

Penelitian ini bertujuan untuk menguji validitas konstruk sikap nasionalisme dengan cara melakukan analisis faktor eksploratori (Suryabrata, 2009). Alat ukur dibuat berdasarkan teori sikap nasionalisme dari Sartono Kartodiredjo (1967, dalam Moesa, 2007) dan Gunawan Restu (1998) yang digabungkan menjadi 7 aspek sikap nasionalisme yaitu: toleransi, tanggung jawab, rela berkorban, sopan santun, peduli terhadap sesama, bersedia menggunakan produk dalam negeri, dan mencintai budaya sendiri. Ketujuh aspek ini di jabarkan melalui 57 item yang akan mengukur sikap nasionalisme pada mahasiswa aktif Universitas Malikussaleh. Subyek penelitian berjumlah 100 orang mahasiswa Universitas Malikussaleh, dengan kriteria mahasiswa aktif Universitas Malikussaleh, berstatus sebagai warga negara Indonesia (WNI), dan bersedia berpartisipasi dalam penelitian.

Ada dua tahap uji validitas dalam penelitian ini, yaitu uji validitas isi dan validitas konstruk. Validitas isi dilakukan melalui expert judgment yang dilakukan melalui pendapat professional. Dalam penelitian ini, setelah instrument dikontruksi tentang aspek-aspek yang akan diukur dengan berlandaskan teori tertentu, maka selanjutnya dilakukan expert judgment oleh individu yang dipandang ahli. Penilaian dilakukan berdasarkan relevan atau tidak relevan item terhadap indikator sikap nasionalisme. Setelah analisis kemudian diadakan revisi yang dikonsultasikan dengan pakar ahli psikologi untuk melihat kekuatan item butir sehingga hasil konsultasi dijadikan masukan untuk membuang butir-butir item yang tidak relevan dan menyempurnakan instrumen sehingga layak untuk digunakan. Selanjutnya, akan dilakukan dua cara dalam menguji validitas konstruk, yaitu melihat korelasi item-total dan melakukan analisis faktor. Dalam menyeleksi item-item yang valid dilakukan korelasi item-total. Besaran koefisien korelasi yang memenuhi syarat untuk dapat diterima adalah 0,3 dengan tetap mempertimbangkan keterwakilan item. Namun, apabila suatu item dapat menggambarkan konsep yang menjadi tujuan pengukuran, maka item tersebut dapat dipertimbangkan dan dipertahankan meskipun nilai korelasi mencapai lebih dari 0,3. (Azwar, 2009). Setelah itu, peneliti melakukan analisis faktor eksploratory (EFA).

Ada dua tahapan yang selanjutnya dilakukan yaitu menentukan variabel dan melakukan ekstraksi faktor dari variable yang ditentukan. Tahapan pertama adalah menentukan besaran nilai Barlett Test of Sphercity yang berfungsi untuk mengetahui adanya korelasi antar variabel. Selanjutnya dilakukan pengukuran kecukupan sampel dengan menggunakan aturan Keiser-Meyers-Oklin (KMO) Measures of Sampling Adequacy. Cara tersebut dilakukan dengan membandingkan besarnya koefisien korelasi yang diamati dengan koefisien korelasi parsialnya. Adapun tahapan kedua peneliti melakukan ekstraksi faktor pada semua variabel. Peneliti mengelompokkan variabel dengan cara merotasi faktor. Tahapan berikutnya adalah penamaan faktor dengan ditentukan oleh muatan faktor yang dijelaskan oleh faktor terhadap setiap variabel. Faktor dengan varians terbesar menjelaskan bahwa faktor itu menjadi faktor umum dari skala sikap Nasionalisme. Tahapan terakhir adalah melakukan uji reliabilitas melalui reliabilitas alpha cronbach. Koefisien reliabilitas bekisar dari skor 0,00 hingga 1,00 sehingga apabila mendekati angka 1.00 maka semakin reliable alat ukur tersebut. 


\section{Hasil Penelitian}

Berdasarkan hasil analisis faktor exploratory, maka hasil penelitian ini dapat diuraikan dalam enam bagian. Bagian pertama adalah pemilihan variabel yang dinilai dari ada tidaknya korelasi antar variabel pengamat. Pada tahap ini, diperoleh hasil nilai Barlett Test of Sphericity adalah 2171.52, dengan taraf signifikansi 0,000 yang berarti ada korelasi yang signifikan di antara variabel pengamat. Hasil perhitungan KMO (Kaiser-Meyer-Olkin Measure of Sampling Adequacy) sebesar 0,626 (p>0,50) menunjukkan bahwa persyaratan pertama sudah dipenuhi sehingga dapat melakukan teknik analisis faktor.

Ekstraksi faktor adalah tahapan kedua yang dilakukan terhadap semua variabel sehingga terdapat 38 item yang di ekstraksi. Berdasarkan grafik hasil ekstraksi faktor, ditemukan lima komponen faktor dengan nilai kumulatif varians sebesar 73,18\%, seperti terlihat pada Gambar 1 yang menunjukkan grafik scree plot.

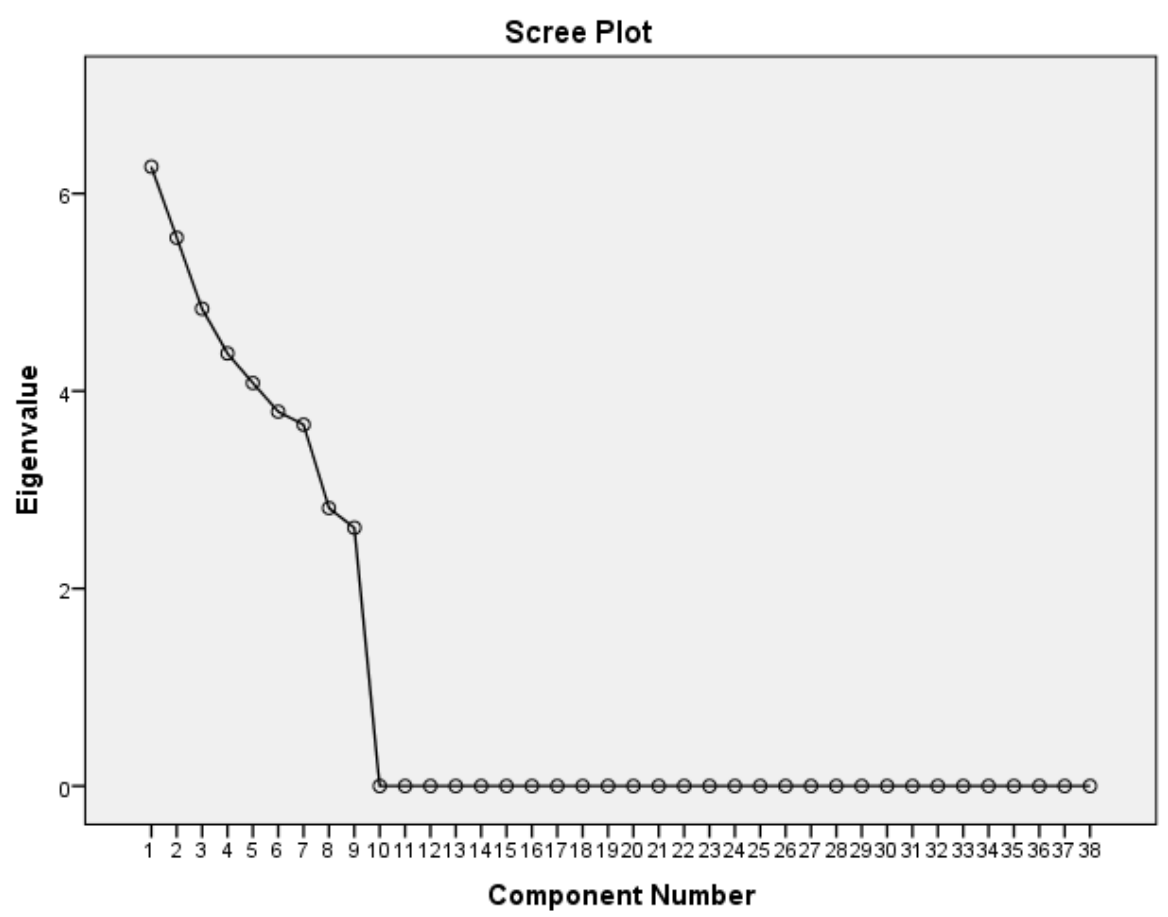

Gambar 1. Grafik Scree Plot

Hasil ekstraksi faktor menggunakan dilaksanakan menggunakan Principal Component Analysis yang menghasilkan lima faktor yang belum dirotasi dengan menggunakan metode ekstraksi Principal Component Analysis seperti yang terlihat pada Tabel 2 di bawah. Faktor pertama menjelaskan varians sebesar 28,89\%, faktor kedua sebesar $14,02 \%$, faktor ketiga sebesar $12,41 \%$, faktor keempat sebesar $10,02 \%$, dan faktor kelima sebesar 7,84\%.

Tabel 2

Principal Component Analysis

\begin{tabular}{cc}
\hline Faktor ke & \% \\
\hline Faktor 1 & 28.89 \\
Faktor 2 & 14.02 \\
Faktor 3 & 12.41 \\
Faktor 4 & 10.02 \\
Faktor 5 & 7.84 \\
\hline
\end{tabular}


Rotasi faktor yang merupakan tahapan ketiga dilakukan dengan metode varimax, karena metode ini berusaha memaksimalkan jumlah varians dalam muatan faktor. Hasil rotasi faktor dapat dilihat pada Tabel 3 dibawah ini:

Tabel 3.

\section{Hasil Rotasi Faktor}

\begin{tabular}{|c|c|c|c|c|c|}
\hline Item & Toleransi & Cinta Budaya & Rela Berkorban & Tanggung Jawab & Cinta Budaya \\
\hline Item 1 & 0,79 & & & & \\
\hline Item 15 & 0,872 & & & & \\
\hline Item 29 & 0,326 & & & & \\
\hline Item 38 & 0,481 & & & & \\
\hline Item 8 & 0,349 & & & & \\
\hline Item 22 & 0,437 & & & & \\
\hline Item 35 & 0,542 & & & & \\
\hline Item 5 & 0,692 & & & & \\
\hline Item 19 & 0,445 & & & & \\
\hline Item 32 & 0,322 & & & & \\
\hline Item 12 & 0,501 & & & & \\
\hline Item 26 & 0,772 & & & & \\
\hline Item 13 & & 0,655 & & & \\
\hline Item 27 & & 0,782 & & & \\
\hline Item 6 & & 0,422 & & & \\
\hline Item 20 & & 0,395 & & & \\
\hline Item 33 & & 0,662 & & & \\
\hline Item 7 & & 0,453 & & & \\
\hline Item 21 & & 0,760 & & & \\
\hline Item 34 & & 0,465 & & & \\
\hline Item 37 & & 0,279 & & & \\
\hline Item 14 & & 0,826 & & & \\
\hline Item 28 & & 0,831 & & & \\
\hline Item 3 & & & 0,415 & & \\
\hline Item 17 & & & 0,407 & & \\
\hline Item 31 & & & 0,524 & & \\
\hline Item 10 & & & 0,470 & & \\
\hline Item 24 & & & 0,123 & & \\
\hline Item 36 & & & 0,491 & & \\
\hline Item 9 & & & & 0,843 & \\
\hline Item 23 & & & & 0,256 & \\
\hline Item 2 & & & & 0,604 & \\
\hline Item 16 & & & & 0,263 & \\
\hline Item 30 & & & & 0,739 & \\
\hline Item 11 & & & & & 0,206 \\
\hline Item 25 & & & & & 0,686 \\
\hline Item 4 & & & & & 0,182 \\
\hline Item 18 & & & & & 0,343 \\
\hline
\end{tabular}

Tahapan keempat adalah penamaan faktor berdasarkan besarnya loading. Item yang masuk ke dalam faktor pertama adalah item 1, 15, 29, 38, 8, 22, 35, 5, 19, 32,12, dan 26. Faktor pertama dinamakan Toleransi. Item 13, 27, 6, 20, 33, 7, 21, 34, 37, 14, dan 28 masuk ke dalam faktor kedua yang dinamakan cinta budaya. Item pada faktor ketiga adalah item 3, 17, 31, 10, 24, dan 36 yang dinamakan rela berkorban. Faktor keempat adalah item 9, 23, 2, 16, dan 30 yang masuk dalam tanggung jawab. Faktor terakhir adalah sopan santun yang terdiri dari item 11,25, 4, dan 18.

Hasil uji Reliabilitas dalam penelitian ini diperoleh skor alpha sebesar 0.808 (yang ditunjukkan oleh tabel 4) berdasarkan estimasi reliabilitas yang dilakukan pada seluruh item. Koefisien Cronbach alpha yang demikian menunjukkan bahwa skala sikap nasionalisme dapat digunakan karena hasil pengukurannya dapat dipercaya berdasarkan nilai reliabilitas yang diperoleh. 
Tabel 4

Reliabilitas Skala Nasionalisme

\begin{tabular}{cc}
\hline $\begin{array}{c}\text { Cronbach's } \\
\text { Alpha }\end{array}$ & N of Items \\
\hline .808 & 38 \\
\hline
\end{tabular}

Tahapan terakhir adalah teknik pengujian validitas isi pada alat ukur sikap nasionalisme ini melalui expert judgement yang dilakukan oleh lima orang professional psikologi. Tahapan ini bertujuan untuk melakukan penilaian terhadap alat ukur sikap nasionalisme yang telah dibuat peneliti. Berdasarkan penilaian dari expert judgment pada 57 item awal skala sikap nasionalisme, diperoleh 19 item yang digugurkan karena tidak sesuai dengan kriteria alat ukur. Selanjutnya ada 38 item final yang disarankan dan disertai konsultasi pakar psikologi. Setelah itu, dilakukan uji validitas kriteria menggunakan teknik korelasi Person Product Moment dan didapatkan nilai sebesar 0,783. Dengan nilai yang diperoleh, maka dapat disimpulkan bahwa item-item pada alat ukur sikap nasionalisme yang dibuat oleh peneliti sudah layak untuk digunakan.

\section{Pembahasan}

Alat ukur yang baik adalah alat ukur yang validitas dan reliabilitasnya baik. Dalam pengembangan alat ukur sikap nasionalisme ini, peneliti berusaha menciptakan alat ukur yang valid dan reliabel dengan cara menggunakan teknik analisis faktor eksploratori. Instrumen ini mengukur sikap nasionalisme mahasiswa di era globalisasi sekarang. Instrumen ini berisi 38 item yang berupa pernyataan dan terbagi dalam lima aspek, yaitu toleransi, cinta budaya, rela berkorban, tanggung jawab, sopan santun.

Aspek toleransi menggambarkan sikap atau tindakan individu dalam menghargai perbedaan sesama bangsa Indonesia seperti perbedaan agama, etnis, dan pendapat. Selain menghargai, individu juga harus mampu hidup tenang dan beradaptasi dengan segala perbedaan yang ada. Aspek tanggung jawab menunjukkan sikap atau tindakan individu dalam melaksanakan kewajiban atau tugas yang berkaitan dengan dirinya sendiri, masyarakat, dan lingkungan sekitar. Aspek cinta budaya berarti merasa bangga dan tidak pernah malu dengan kebudayaan bangsa Indonesia dan bersedia menggunakan produk dalam negeri. Aspek rela berkorban berusaha melihat kesediaan individu dalam mendahulukan kepentingan orang lain dibandingkan kepentingan diri sendiri. Aspek sopan santun melihat sifat halus dan baik yang ada pada individu dari sudut pandang tata bahasa maupun tata perilakunya ke semua orang sesuai dengan tataran norma lingkungannya.

Pengukuran sikap nasionalisme telah dimunculkan oleh beberapa skala sebelumnya. Namun, kuesioner dan juga alat ukur dalam penelitian ini menggabungkan pendapat atau teori dari dua ahli sehingga lebih menggambarkan sikap nasionalisme dan menjadi layak untuk digunakan dalam melihat sikap nasionalisme. Selain itu, belum adanya skala sikap nasionalisme yang dibuat dengan tujuan subjek mahasiswa, sehingga peneliti melakukan pengembangan alat ukur sikap nasionalisme pada mahasiswa berlatar belakang dengan alasan tersebut.

Dalam melihat penyebaran komponen dan rotasinya, instrumen dalam alat ukur sikap nasionalisme ini diuji dengan menggunakan SPSS. Hasil yang diperoleh adalah tujuh aspek sikap nasionalisme yang mengacu pada teori Sartono Kartodirojo (1967) dan Gunawan Restu (1998) menyatu menjadi lima komponen dan diberikan penamaan baru pada kelima komponen tersebut. Hasil analisis faktor eksploratori instrumen sikap nasionalisme ini menghasilkan lima komponen yaitu toleransi, cinta budaya, rela berkorban, tanggung jawab, dan sopan santun. 


\section{Kesimpulan dan Saran}

Sikap nasionalisme pada mahasiswa dapat diukur melalui instrumen sikap nasionalisme yang telah disusun oleh peneliti. Tahapan-tahapan yang dilakukan dalam melakukan analisis dilaksanakan secara berurutan sehingga skala yang dibuat akurat dan dapat dipercaya. Instrumen ini telah diuji validitas dan reliabilitasnya menggunakan validasi konten oleh expert judgment serta menggunakan SPSS dengan melihat rotasi dan penyebaran komponennya. Hasil akhir didapatkan lima komponen atau aspek baru dalam sikap nasionalisme, yaitu toleransi, cinta budaya, rela berkorban, tanggung jawab, dan sopan santun. Hasil uji validitas mendapatkan 38 item yang dapat digunakan untuk mengukur sikap nasionalisme. Meskipun angka reliabilitas didapatkan dalam instrumen ini tergolong baik yaitu 0,808 namun disarankan kepada peneliti selanjutnya untuk melakukan uji coba kembali pada subjek yang berbeda.

\section{Daftar Pustaka}

Affan, H., \& Hafidh, M. (2016). Membangun Kembali Sikap Nasionalisme Bangsa Indonesia dalam Menangkal Budaya Asing di Era Globalisasi. Jurnal Pesona Dasar, Vol.3 (4).

Anwar, C. (2014). Internalisasi Semangat Nasionalisme Melalui Pendekatan Habituasi (Perspektif Filsafat Pendidikan). Analisis: Jurnal Studi Keislaman, 14(1), 159-172.

Aviani, R. R. (2019). Pengaruh Modernisasi terhadap Semangat Nasionalisme dan Gotong Royong pada Generasi Muda.

Azwar, S. (2002). Penyusunan Skala Psikologi. Yogyakarta: Pustaka Pelajar.

Azwar, S. (2009). Metode penelitian.Yogyakarta: Pustaka Belajar.

Buasan, B. (2012). Mari Tumbuhkan Jiwa dan Semangat Nasionalisme. Perilaku Nasionalistik Masa Kini dan Ketahanan Nasional. Yogyakarta: Mata Bangsa.

Eddy, K, dkk. (2002). Pendidikan Kewarganegaraan. Yogyakarta: UPT MKU UNY.

Kartodirdjo, S. (1967). Kolonialisme dan Nasionalisme di Indonesia abad XIX-XX. Diterbitkan oleh Seksi Penelitian Djurusan Sedjarah Fakultas Sastra dan Kebudajaan Universitas Gadjah Mada.Suryabrata, S. (2010). Metodologi Penelitian. Jakarta: PT. Raja Grafindo.

Manan, A. (2011). Nasionalisme dan Ketahanan Budaya di Indonesia. Jakarta: LIPI Press.

Moesa, A. (2007). Nasionalisme Kiai: Konstruksi Sosial Berbasis Agama. Surabaya: LkiS.

Mustari, M. (2014). Nilai Karakter Refleksi untuk Pendidikan. Jakarta: Raja Grafindo Persada.

Mutia, T. (2018). Generasi Milenial, Instagram Dan Dramaturgi: Suatu Fenomena Dalam Pengelolaan Kesan Ditinjau Dari Perspektif Komunikasi Islam. An-Nida', 41(2), 240-251.

Parmoto, T. (2012). Penerapan Perilaku Nasionalistik Masa Kini. Perilaku Nasionalistik Masa Kini dan Ketahanan Nasional. Yogyakarta: Mata Bangsa.

Restu, G. (1998). Simposium Pengajaran Sejarah (Kumpulan Makalah Diskusi). Jakarta: Depdikbud.

Sadikin. (2008). Peningkatan Sikap Nasionalisme melalui Pembelajaran IPS dengan Metode Sosiodrama di SD Cikembulan, Banyumas. Tesis. Yogyakarta: Universitas Negeri Yogyakarta.

Sardjo., \& Setiawan, L. (2019). Sikap Nasionalisme di SMP Negeri 1 Muaro Jambi. Jurnal Publikasi Pendidikan, Vol. 9 (2), 11-18.

Suryabrata, S. (2010). Metodelogi Penelitian. Jakarta: PT. Raja Grafindo.

Suriata, I. N. (2019). Aktualisasi Kesadaran Bela Negara Bagi Generasi Muda Dalam Meningkatkan Ketahanan Nasional.Public Inspiration: Jurnal Administrasi Publik, 4(1), 47-56. 
Tilaar, H. (2007). Mengindonesia Etnisitas dan Identitas Bangsa Indonesia. Jakarta: RT. Rineka Cipta.

Triantoro, H. B. (2008). Erosi Rasa Kebangsaan Indonesia. Yayasan Pananjung Wibawa Mukti: Jakarta.

Yasa, I. M. S. (2012). Pengembangan Alat Ukur Sikap Nasionalisme Pada Siswa RSBI SMA Negeri 1 Gianyar Tahun Pelajaran 2011-2012.Jurnal Penelitian dan Evaluasi Pendidikan Indonesia, 2(2), 24-30. 